\title{
Identifying prey of the Javan mongoose (Urva javanica) in Java from fecal samples using next-generation sequencing
}

\section{Sena A. Subrata, Stefanie R. T. Siregar, Adrien André \& Johan R. Michaux}

\section{Mammalian Biology}

Zeitschrift für Säugetierkunde

ISSN 1616-5047

Volume 101

Number 1

Mamm Biol (2021) 101:63-70

DOI 10.1007/s42991-020-00086-y 
Your article is protected by copyright and all rights are held exclusively by Deutsche Gesellschaft für Säugetierkunde. This eoffprint is for personal use only and shall not be self-archived in electronic repositories. If you wish to self-archive your article, please use the accepted manuscript version for posting on your own website. You may further deposit the accepted manuscript version in any repository, provided it is only made publicly available 12 months after official publication or later and provided acknowledgement is given to the original source of publication and a link is inserted to the published article on Springer's website. The link must be accompanied by the following text: "The final publication is available at link.springer.com". 


\title{
Identifying prey of the Javan mongoose (Urva javanica) in Java from fecal samples using next-generation sequencing
}

\author{
Sena A. Subrata ${ }^{1}$ (1) - Stefanie R. T. Siregar ${ }^{2}$ - Adrien André $^{3}$ - Johan R. Michaux ${ }^{3}$
}

Received: 13 November 2019 / Accepted: 7 November 2020 / Published online: 30 November 2020

○ Deutsche Gesellschaft für Säugetierkunde 2020

\begin{abstract}
The Javan mongoose (Urva javanica) is a mesopredator native to Java island that has been rarely studied. The limited information raises questions as to its ecological roles, particularly in terms of its effects on agriculture and biodiversity. These questions are critical as its congeneric species, the small Indian mongoose, has been listed among the 100 worst invasive species. To disclose its ecological function, a new approach that is capable of revealing the diet of the Javan mongoose at the species level is required. We conducted this study to identify the prey species of the Javan mongoose using next-generation sequencing methodology. Our study was conducted in a forested area of the southern mountains of Java, Indonesia. We collected fecal samples during the dry season of March-October 2018, extracting DNA using a QIAamp Fast DNA Stool Mini Kit. We performed Illumina sequencing using a 133 bp mini-barcode of the Cytochrome Oxidase I gene. Our rigorous analysis found 17 species, 14 genera, and 12 families of vertebrates and invertebrates in the mongoose feces. The greater bandicoot rat (Bandicota indica) and the domestic chicken (Gallus gallus) made up the primary diet of the Javan mongoose. Cricket, ant, moth, and fly species were also found in the feces. In effect, our results suggested that this species has a relatively diverse diet, one that includes mammals, birds, amphibians, snakes, fish, and many invertebrates. It confirms that the Javan mongoose has an opportunistic diet, which is most likely related to the availability of putative prey.
\end{abstract}

Keywords Mammals $\cdot$ High-throughput sequencing $\cdot$ eDNA $\cdot$ Role $\cdot$ Fecal

\section{Introduction}

There are a limited number of studies on the ecology and diet of the Javan mongoose (Urva javanica), with several reports on its phylogeny (Veron et al. 2007), as well as geographic distribution (Veron and Jennings 2017). However, this limited information on its ecology and diet is also a consequence of this species' taxonomic separation, with Herpestes javanicus split into two different species, namely the Javan mongoose (Urva javanica) and small Indian

Handling editor: Pamela Burger.

Sena A. Subrata

adisubrata@ugm.ac.id

1 Faculty of Forestry, Universitas Gadjah Mada, J1. Agro No. 1. Bulaksumur, Yogyakarta 55281, Indonesia

2 Universitas Atmajaya Yogyakarta, J1. Babarsari No. 44, Babarsari, Yogyakarta 55281, Indonesia

3 Conservation Genetics Unit, Department of Life Sciences, University of Liège, 4000 Liege, Belgium mongoose (Urva auropunctata) (Veron and Jennings 2017). Several reports referred to Urva auropunctata as Herpestes javanicus in its introductory range. Only a few studies have been conducted on Urva javanica in Java, specifically. Therefore, this research examined the ecological information and diet of Javan mongoose in Java island.

The lack of information on the Javan mongoose raises questions regarding the ecological roles of this species. One of its congeneric species, the small Indian mongoose, has a positive impact on its ecosystem and is known for its ability to control both insect and rat pest populations in its native range (Mahmood and Adil 2017). However, in its non-native ranges, the small Indian mongoose tends to negatively affect local biodiversity. This high variance in ecological impact is related to its opportunistic feeding behavior, as observed by Mahmood and Adil (2017).

As we have learned from the small Indian mongoose's case, it is important to have a detailed understanding of the diet of the Javan mongoose to avoid population mismanagement, which leads to a harmful effect for biodiversity. While past researches [e.g. Seaman and Randall (1962), Gorman (1975), 
and Mahmood and Adil (2017)] may contribute to our understanding of the variation of the small Indian mongoose's feeding behavior effects, these studies lack detail. In the past, this species was believed to feed on rats; therefore, its introduction to agricultural land in the Virgin islands was justified as a form of pest control (Seaman and Randall 1962). Additional studies have revealed a more diverse diet than previously thought. Gorman (1975) found that insects make up a significant fraction of the mongoose's diet on Fijian archipelago. In their native range, they are also known to consume seeds, stems and leaves (Mahmood and Adil 2017). These reports describe a wide variation in diet composition, and at a broader taxonomic scale than the species level. The lack of information on the diet make-up at the species level may lead to inconsistent summations. It also speaks to the difficulty of collecting data.

Studies on the diet of the mongoose also present a methodological challenge. The aforementioned dietary data of the small Indian mongoose were mostly obtained using microhistological observation of feces or gut contents. However, these approaches are not comprehensive enough to reveal details of the food items, and misidentification of the remnants at the species level can occur due to fragmented tissue (Casper et al. 2007; Litvaitis and Pearl 2000). Most of the results generated using these approaches have only given information at the genus or higher taxonomic levels (Zeale et al. 2011). For purely appraisal purposes, this approach may be suitable. However, for population management, such as biological control of prey populations, a better approach capable of identifying the diet of a targeted species is required.

Recently, the metabarcoding approach using a next-generation sequencer (NGS) has been developed to identify species from composite samples, like feces. This approach has been applied for the study of many wildlife species' diets, including bats (Zeale et al. 2011; Andriollo et al. 2019), water shrews (Biffi et al. 2017), leopards (Shehzad et al. 2012), as well as more challengingly small creatures like spiders (Macías-Hernández et al. 2018). This approach is able to overcome difficulties in identifying the bulk of species through food remnants found in feces and has been acknowledged to be more precise than morphological observation (Mumma et al. 2016). In our study, we used this approach to identify the prey of the Javan mongoose at the species level. Providing this information may reveal the ecological role of the species for agricultural purposes and may also be beneficial for its population management.

\section{Materials and methods}

This study was conducted in a forested area of the southern mountains of Yogyakarta, on the island of Java in Indonesia (Fig. 1). This is the known geographic range of the
Javan mongoose and is predominantly a karst ecosystem previously covered by monsoon forests. In this area, the mongoose coexists with other meso-predators, such as the leopard cat (Prionailurus bengalensis), common palm civet (Paradoxurus hermaphroditus), Asian small-clawed otter (Aonyx cinerea), and small Indian civet (Viverricula indica). In small parts of the area, remnants of the natural forest still exist alongside restoration forest spaced by agroforestry land and are close to villages. We conducted fieldwork, collecting putative feces samples in both the naturally occurring and restoration forests, during the dry season of March-October 2018. In the first step of feces collection, feces of the species were identified in the field based on morphological recognition. In the second step, Javan mongoose feces were confirmed using genetic tools using a Cytochrome Oxidase I (COI) gene sequence, which was retrieved from GenBank (accession number: NC_006835) originating from a Fiji sample. Although suboptimal, this selection method was used due to the unavailability of the COI sequence from Java.

Once found, feces were placed in a $50 \mathrm{ml}$ plastic tube preloaded with silica beads to preserve the feces. Drypreserved feces were stored in a freezer (c.a. $4{ }^{\circ} \mathrm{C}$ ) until the time of DNA extraction (1-2 weeks). We recorded geographic coordinates and habitat types along with the feces' identity. We then extracted DNA from the feces samples using a QIAamp Fast DNA Stool Mini Kit (Qiagen, Hilden, Germany). Before following the manufacturer's protocol, we conducted a pre-treatment consisting of incubating $0.8-1.6 \mathrm{~g}$ of feces in a $5 \mathrm{ml}$ ASL buffer (Qiagen, Germany) at $65{ }^{\circ} \mathrm{C}$ for $1 \mathrm{~h}$. This pre-treatment was performed to promote cell lysis, particularly of possible bones, hairs, and chitin remnants that could be found in the feces of the Javan mongoose. Following pre-treatment, fecal samples were processed in accordance with the manufacturer's protocol. Extracted DNA was quantified using a Qubit 2.0 fluorometer. We eliminated samples that had a concentration of less than $1 \mathrm{ng} / \mu \mathrm{l}$. The libraries were prepared following a two-step PCR approach, combined with Illumina's dual indexing strategy: a $133 \mathrm{bp}$ minibarcode was amplified using the primer couple developed by Hebert et al. (2004). The PCR was carried out using a $25 \mu$ reaction volume with $5 \mu$ l of KAPA Hifi Fidelity buffer (Roche, Switzerland), $0.75 \mu$ l of dNTPs, $0.75 \mu$ l of each primer, $1 \mu$ of KAPA HiFi DNA Polymerase (Roche, Switzerland), $13.25 \mu \mathrm{l}$ of PCR-grade water, and $3.5 \mu \mathrm{l}$ of DNA extract. The PCR methodology consisted of an initial denaturation step at $95^{\circ} \mathrm{C}$ for $5 \mathrm{~min}$, followed by 38 cycles of denaturation at $95{ }^{\circ} \mathrm{C}$ for $30 \mathrm{~s}$, annealing at $45^{\circ} \mathrm{C}$ for $45 \mathrm{~s}$, an extension step at $72{ }^{\circ} \mathrm{C}$ for $30 \mathrm{~s}$, followed by a final extension step at $72{ }^{\circ} \mathrm{C}$ for $10 \mathrm{~min}$. The resulting PCR products were purified using Agencourt AMPure XP beads (Beckman and Coulter, USA). 


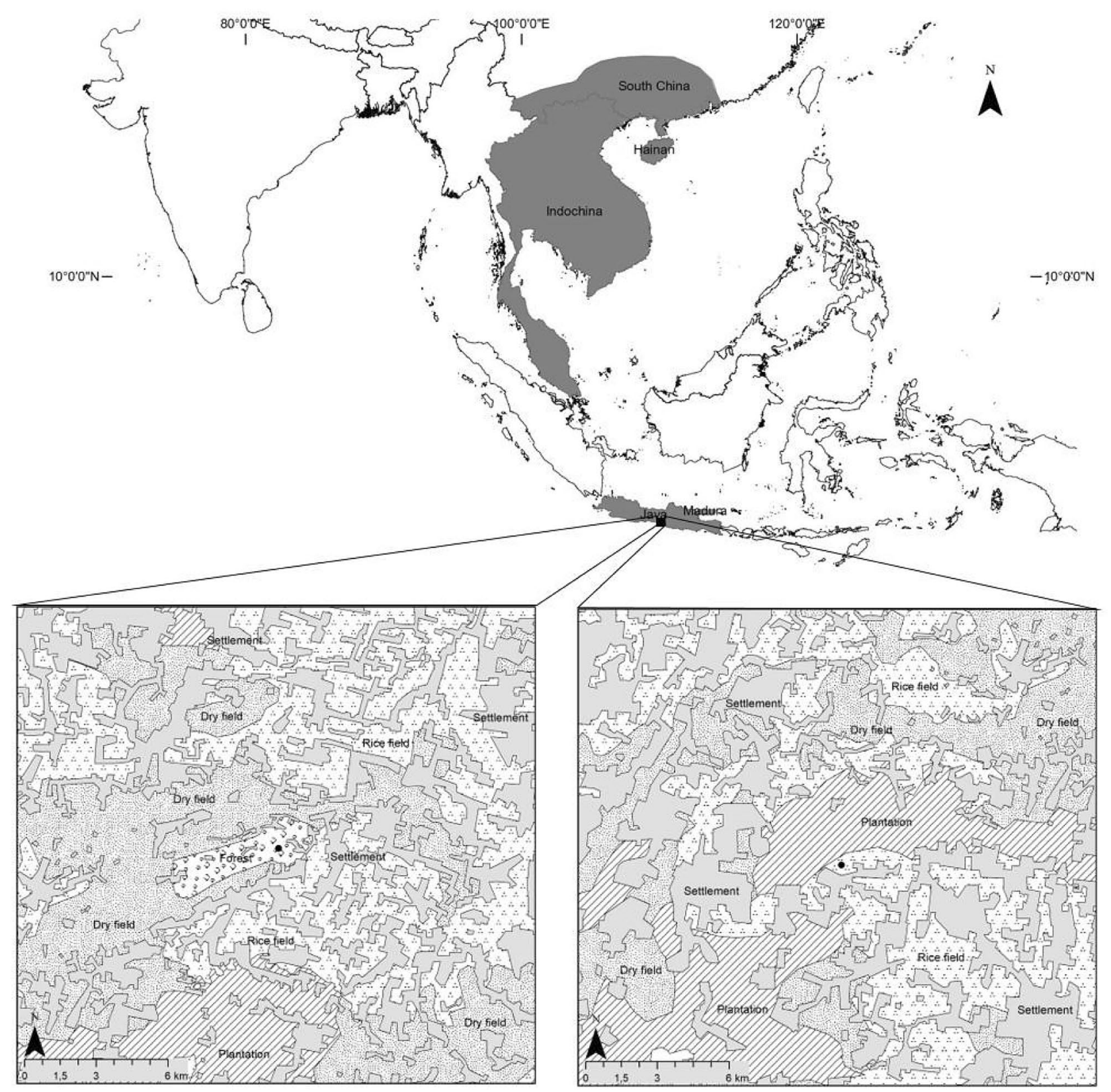

Fig. 1 Geographic range of the Javan mongoose and land cover of the research sites (left: natural forest; right: restored forest). The dots represent a location where the majority of the samples have been col-

A second round of PCR was performed to add the dual indexes and the adaptor required by the Nextseq sequencer, following the protocol developed by Illumina. A second purification was performed followed by a quantification of each resulting purified PCR product using a FISHER QuantiT PicoGreen ${ }^{\circledR}$ dsDNA Assay Kit (Thermo Fischer, USA). All samples were then diluted to $5 \mathrm{ng} / \mu \mathrm{l}$, pooled together and subsequently transported with pools from other projects lected, which are surrounded by dry-fields, settlements, rice fields, plantation agroforestry lands, and forests (Redrawn from Veron and Jennings 2017)

to the GIGA NGS platform from the University of Liege, France, for sequencing on a Nextseq Illumina Sequencer. The raw sequences were treated using a modified version of the bioinformatic script found in André et al. (2017), consisting of both the FASTX Toolkit 23-09-16 and USEARCH (Edgar 2010) functions. The resulting sequences were then compared with published sequences available in the BOLD database (Ratnasingham and Hebert 2007). 


\section{Results}

Although we had to discard many unqualified samples and data, we successfully identified prey species of the Javan mongoose using NGS technology. The feces samples were found mostly at the edge of natural and restored forests (plantations), adjacent to rice fields, as shown in Fig. 1. The locations are close to the village's dry field and plantation, with the habitat exposed to sunlight, thereby causing the DNA of the feces to be prone to degradation. From more than 100 samples collected in the field, only 15 samples were included (DNA concentration: $1.0-5.9 \mathrm{ng} / \mu \mathrm{l}$ ) for molecular identification using NGS. The rest were discarded because the DNA quantity was less than $1 \mathrm{ng} / \mu \mathrm{l}$.

Our results showed that all 15 samples provided sequences of data consisting of short fragments of the mitochondrial COI gene. After removing the sequence of contaminants and species with a percentage matching score-lower than $98 \%$ for Chordata and less than $95 \%$ for Arthropoda databases-we obtained 1,623,701 sequences. They consisted of 1,201,714 vertebrate and 421,987 invertebrate sequences. Besides contaminants and matching score issues, unreliable identification was also a concern. We excluded sequences from the lists if the sequence count was less than $1 \%$. We applied this setting for the vertebrate and invertebrate databases separately. Ultimately, 1,608,087 sequences were used for further analysis. More than half of the sequences were identified correctly (100\% match). Onethird of the vertebrate sequences were determined, with a match score of $98-98 \%$.

In contrast, a low number of invertebrate sequences were identified at this last level (Table 1). Almost half of the Arthropoda sequences were identified (95-97\% match score). However, these particular identifications need to be taken with caution because sequence databases for arthropods living in the tropics are incomplete.

Sequences of Javan mongooses were identified in all 15 analyzed feces, confirming that they were produced by this species. Furthermore, the identification was based on the BOLD and GenBank databases under the name of Herpestes javanicus. Moreover, our rigorous analysis showed evidence

Table 1 Sequence count and match percentage after trimming at $1 \%$ threshold

\begin{tabular}{llc}
\hline \% Match & \multicolumn{2}{l}{ Sequence count } \\
\cline { 2 - 3 } & Chordata database & Arthropoda database \\
\hline $95-97$ & 0 & $198,638(47 \%)$ \\
$98-99$ & $213,630(18 \%)$ & $3677(1 \%)$ \\
100 & $976,681(82 \%)$ & $215,461(52 \%)$ \\
Total & $1,190,311(100 \%)$ & $417,776(100 \%)$ \\
\hline
\end{tabular}

of 24 taxa in these fecal samples, corresponding to 17 species, 14 genera, 12 families, and 12 orders of vertebrates and invertebrates (Table 2). We identified all vertebrates at the species level, with the exception of one species of the Anuran order. In contrast, we were only able to identify half of the invertebrate sequences at the species level. From 17 species, half of them were identified with a perfect match with the available databases (three rats, two birds, and five insect species).

Meanwhile, the rest of the taxa were identified less precisely, but still had an adequate match score. From the identified species, two birds (Gallus gallus and Cairina moschata) were poultry species, and four rats are known as agricultural pests. The greater bandicoot rat (Bandicota indica) was the most common mammalian species identified. In addition, three other rat species with a smaller body mass were identified at a lower frequency of occurrence. Bandicota indica and Rattus tanezumi are introduced species, while Rattus tiomanicus and Rattus argentiventer are native species of Java. Lastly, a snake species, Ptyas mucosa was evidenced at a low level of occurrence.

Along with the greater bandicoot rat, the domestic chicken ( $G$. gallus) comprised the primary diet of the mongoose. We found both species in half of the analyzed fecal samples (Table 2). Finally, cricket, ant, moth, and fly species were also found. The majority of the insect groups found in the feces corresponded to scavenger species.

\section{Discussion}

Research concerning the ecological role of mesopredators has re-emerged recently using a new molecular approach (Monterroso et al. 2019). Specifically for mongooses (Herpestids) in their native habitat, past knowledge has been unclear on whether these mesopredator species have a positive or negative impact on the ecosystem, due to unspecific dietary data (e.g. Kalle et al. 2012; Mahmood and Adil 2017). Now, advancements in molecular identification provide a methodology to collect more detailed and reliable data on the diet structure of species, potentially clarifying their role as a mesopredator in any given ecosystem. Here, we reported the diet composition of a herpestid mesopredator in the island of Java, the Javan mongoose. We showed that a metabarcoding technique using a PCR primer to amplify a short fragment of the COI gene is capable of revealing the high dietary variability of this species.

The successfulness of species identification using a metabarcoding technique depends heavily on the appropriate selection of the marker being used, the reference database, the taxonomic scope, the DNA quality, and the amplicon length (Devloo-Delva et al. 2018). Our sampling sites were characterized by both high levels of ultraviolet light 
Table 2 Taxa identified from feces of the Javan mongoose using mini-barcoding of the Cytochrome Oxidase I (COI) gene

\begin{tabular}{|c|c|c|c|c|c|}
\hline Order & Family & Genus & Species & $\%$ Match score & $\begin{array}{l}\text { Freq. of } \\
\text { occurrence } \\
(\%)\end{array}$ \\
\hline Rodentia & Muridae & Bandicota & B. indica & 98-99 & 53 \\
\hline Rodentia & Muridae & Rattus & R. tanezumi & 100 & 7 \\
\hline Rodentia & Muridae & Rattus & R. tiomanicus & 100 & 7 \\
\hline Rodentia & Muridae & Rattus & R. argentiventer & 100 & 13 \\
\hline Anseriformes & Anatidae & Cairina & C. moschata & 100 & 7 \\
\hline Galliformes & Phasianidae & Gallus & G. gallus & 99-100 & 53 \\
\hline Anura & - & - & - & 100 & 27 \\
\hline Squamata & Colubridae & Ptyas & P. тисова & 99 & 7 \\
\hline Perciformes & Channidae & Channa & C. gachua & 99 & 13 \\
\hline Orthoptera & Tettigoniidae & Hexacentrus & H. japonicus & 99-100 & 13 \\
\hline Orthoptera & Tettigoniidae & Mecopoda & M. elongata & 99-100 & 15 \\
\hline Orthoptera & Acrididae & Coryphistes & - & 98 & 7 \\
\hline Orthoptera & Acrididae & Diabolocatantops & - & $96-97$ & 5 \\
\hline Hymenoptera & Formicidae & Monomorium & M. floricola & 100 & 7 \\
\hline Hymenoptera & Formicidae & - & - & 100 & 7 \\
\hline Hymenoptera & - & - & - & $96-100$ & 27 \\
\hline Lepidoptera & - & - & - & 96 & 40 \\
\hline Lepidoptera & Tineidae & Monopis & M. monachella & 96 & 40 \\
\hline Lepidoptera & Tineidae & Monopis & M. pavlovskii & 96 & 40 \\
\hline Diptera & Lauxaniidae & Drosophila & D. ananassae & 100 & 7 \\
\hline Diptera & Psychodidae & Psychoda & P. alternata & 99 & 13 \\
\hline Diptera & Calliphoridae & Hemipyrellia & H. ligurriens & 100 & 27 \\
\hline Diptera & Calliphoridae & Lucilia & L. sinensis & 97 & 20 \\
\hline Hemiptera & - & - & - & 99 & 7 \\
\hline Decapoda & - & - & - & 95 & 7 \\
\hline 12 & 12 & 14 & 17 & & \\
\hline
\end{tabular}

Bold line represent perfect identification intensity and humidity, which together quickly degraded the DNA quality of the feces. We anticipated this challenge by selecting a marker with a short sequence that still possessed enough sequence variance for animal identification. To date, the COI gene, along with its extensive reference database, is still acknowledged as the standard marker for animal identification (Marquina et al. 2019). This being said, the entirety of the COI gene is too long and is less likely to be amplified from a degraded DNA template. Therefore, we selected a mini-barcoding marker developed from the COI gene, a fragment initially developed as a marker for the Pyrenean desman, Galemys pyrenaicus (Gillet et al. 2015). Indeed, this marker has already been used to study the diet of several mammalian species, therefore making it an excellent candidate for the study of the diet of a carnivore in the tropics through fecal collection. Using this marker, we were able to identify almost all the vertebrates found in the diet of the Javan mongoose (nine species; Table 2).

Our results showed that, in the tropics, the availability of a reference database, DNA quality, and contaminants influenced species identification of invertebrates using a metabarcoding approach. As such, we were not able to identify almost half of the invertebrate species found. Although we provided more sequences for our analyses compared with the marker performance in identifying prey species of the Pyrenean desman (Gillet et al. 2015), our results clearly showed a lower resolution, likely due to the incomplete databases that exist for tropical insects (Beng et al. 2016). This inadequacy was compounded by the difficulty of obtaining high-quality insect sequences from mongoose feces, because of a relatively low number of sequences (Table 1). This led to only moderate success in species identification. Moreover, the low DNA quality of the feces samples due to the tropical climate was likely correlated with this problem, as indicated by the low proportion of DNA successfully isolated (less than 20\%). Besides quality of identification, we were also concerned about DNA contamination from non-food species. Specifically, feces found were probably contaminated by insect eggs before samples were collected. Fresh feces attracts many scavenging insects to lay their eggs, and 
metabarcoding may falsely identify the eggs as part of the consumed diet of the mongoose. However, this final challenge has only been anticipated recently (Ando et al. 2018), and continues to represent a limitation of the metabarcoding approach for the diet analysis of wildlife.

Identifying the details of an animal's diet helps their population management. Even with our limited sample size as an example, we clarified the ecological role of the Javan mongoose through the identification of its prey at the species level. Our results showed that the Javan mongoose in our sampling sites consumed two native species of Muridae: $R$. argentiventer and $R$. tiomanicus, and two introduced species, $B$. indica and $R$. tanezumi. They most frequently fed on $B$. indica (Table 1 ). Mongooses have the ability to control the population of these agricultural pests. However, their natural predation is not effective in eliminating them due to the difference in active time between the species. Indeed, populations of the latter species would be affected weakly at best, because it was shown that the mongooses fed on Rattus species only rarely. Conversely, this mongoose species may help to maintain the population equilibrium of pest species through their interactions with other carnivorous species. Meanwhile, of concern, we found that the Javan mongoose preyed upon chickens (G. gallus), providing evidence of harm to poultry farming. These adverse effects potentially occur as a result of the degradation of the Javan mongoose's natural habitat which has been turned into settlements and other forms of anthropogenic land uses. In addition, we found no evidence of threats to biodiversity from this species.

As reported by Mahmood and Adil (2017), based on limited information on the insect species preyed upon by mongooses, it is presumed that they play a beneficial role in controlling populations of pest insects, in accordance with its congeneric species, Urva auropunctata, in India. That said, our study showed quite different data. Of the known insect pests, we found only fruit flies (Drosophila ananassae) in the diet of the mongooses we sampled. These species are known for their destructive behavior in agriculture (ElEla et al. 2013; Karremans et al. 2015); therefore, controlling their populations should benefit farmers. However, we also found that the Javan mongoose tended to consume flower ants (Monomorium floricola) which prey on the eggs of other insects. Because of this beneficial effect, reduction of these ant populations by the mongoose is not favorable.

Overall, a substantial proportion of the insect species detected in the mongoose feces was composed of scavengers, as evidenced by metabarcoding. Bush crickets (Hexacentrus japonicus and Mecapoda elongata), moths (Monopis monachella and M. pavlovski), and flies (Psychoda alternata, Hemipyrellia liguriens, and Lucilla sinensis) are known to prey upon dead organisms, either at the larval or adult stages (Elbardicy et al. 2009; ElEla et al. 2013; Hinton
1956; Kurahashi et al. 1997; Robinson and Pratt 1975; Turbanova et al. 2019; Way and Khoo 1992). The wide variety of insects in their feces may be due to the generalist trait of the mongoose or the methodological weakness in our study. These pieces of evidence may show that the mongoose controls the populations of not only agricultural pests, but also insects that are beneficial to agriculture. However, there is a possibility that this indication is untrue, due to the incorrect prey identification. The metabarcoding system may falsely detect insects that were not eaten by the Javan mongoose, yet still found in the feces when it was sampled. This study showed that there is a limitation associated with the use of metabarcoding for diet analysis. The above-listed evidence was based on the occurrence of the remaining DNA in the feces without prior information on the predation. In addition, there is a possibility that the insects were not eaten by the mongoose, rather they were attracted, trapped, or attached to the feces. The possibility is high for decomposer insects, while the environmental contamination is an intrinsic limitation of DNA-based diet analysis that is challenging and impossible to overcome (Taberlet et al. 2018). This challenge was anticipated by removing sequences that were less than 100 counts and assuming that the rest originated from organisms intentionally or accidentally eaten by the mongooses.

Furthermore, these data were inferred from detailed diet analyses in the short term and with a limited spatial scale; therefore, it needs to be interpreted as a preliminary study. The diet composition of the Javan mongoose tends to correlate with food availability in its habitat. Additional research is needed to reveal the indirect effect of its prolonged temporal interactions in the ecosystem, such as in areas with less anthropogenic food sources.

\section{Conclusion}

In general, our study showed minor differences from other reports on the diet of the small Indian mongoose, which is a closely related species of the Javan mongoose. In particular, our results provided evidence that this species has a muchdiversified diet that includes mammals, birds, amphibians, snakes, fish, and many invertebrates. It confirms that the Javan mongoose is an opportunistic predator, which is probably related to the availability of putative prey. The substantial frequency of occurrence of rodent species (Rattus genera) in the feces also evidenced the role of the mongoose as a regulator of pest species. However, our results also revealed its predation of domestic species like chickens, but showed no evidence of a biodiversity threat.

Acknowledgements We are grateful for a research grant awarded from Universitas Gadjah Mada and the Ministry of Research, Technology, 
and Higher Education of Indonesia (research contract no. 64/UN1/ DITLIT/DIT-LIT/LT/2018), which enabled us to conduct this study.

\section{Compliance with ethical standards}

Conflict of interest On behalf of all authors, the corresponding author states that there is no conflict of interest.

\section{References}

Ando H, Fujii C, Kawanabe M, Ao Y, Inoue T, Takenaka A (2018) Evaluation of plant contamination in metabarcoding diet analysis of a herbivore. Sci Rep 8:2-11. https://doi.org/10.1038/s4159 8-018-32845-w

André A, Millien V, Galan M, Ribas A, Michaux JR (2017) Effects of parasite and historic driven selection on the diversity and structure of a MHC-II gene in a small mammal species (Peromyscus leucopus) undergoing range expansion. Evol Ecol 31:785-801

Andriollo T, Gillet F, Michaux JR, Ruedi M (2019) The menu varies with metabarcoding practices: a case study with the bat Plecotus auritus. PLoS ONE 14(7):e0219135. https://doi.org/10.1371/journ al.pone.0219135

Beng KC, Tomlinson KW, Shen XH, Surget-Groba Y, Hughes AC, Corlett RT, Slik JWF (2016) The utility of DNA metabarcoding for studying the response of arthropod diversity and composition to land-use change in the tropics. Sci Rep 6:1-13. https://doi. org/10.1038/srep24965

Biffi M, Laffaille P, Jabiol J, André A, Gillet F, Lamothe S, Michaux JR, Buisson L (2017) Comparison of diet and prey selectivity of the Pyrenean desman and the Eurasian water shrew using nextgeneration sequencing methods. Mamm Biol 87:176-184. https ://doi.org/10.1016/j.mambio.2017.09.001

Casper RM, Jarman SN, Deagle BE, Gales NJ, Hindell MA (2007) Detecting prey from DNA in predator scats: a comparison with morphological analysis, using Arctocephalus seals fed a known diet. J Exp Mar Bio Ecol. https://doi.org/10.1016/j.jembe 2007.04.002

Devloo-Delva F, Huerlimann R, Chua G, Matley JK, Heupel MR, Simpfendorfer CA, Maes GE (2018) How does the marker choice affect your diet analysis? Comparing genetic markers and digestion levels in metabarcoding of reef predator gut content. Mar Freshw Res 70:8-18

Edgar R (2010) Usearch. Lawrence Berkeley National Lab. (LBNL), Berkeley, CA, USA

Elbardicy S, Tadros M, Yousif F, Hafez S (2009) Predatory activity of Psychoda alternata (Diptera: Psychodidae) larvae on Biomphalaria glabrata and Lymnaea natalensis snails and the freeliving larval stages of Schistosoma mansoni. Aust J Basic Appl Sci 3:4503-4509

ElEla SA, ElSayed W, Nakamura K (2013) Mandibular structure, gut contents analysis and feeding group of orthopteran species collected from different habitats of Satoyama area within Kanazawa City, Japan. J Threat Taxa 02:849-857. https://doi.org/10.11609 /jott.o2346.849-57

Gillet F, Tiouchichine ML, Galan M, Blanc F, Némoz M, Aulagnier S, Michaux JR (2015) A new method to identify the endangered Pyrenean desman (Galemys pyrenaicus) and to study its diet, using next generation sequencing from faeces. Mamm Biol 80:505-509. https://doi.org/10.1016/j.mambio.2015.08.002

Gorman ML (1975) The diet of feral Herpestes auropunctatus (Carnivora: Viverridae) in the Fijian Islands. J Zool 175:273-278. https://doi.org/10.1111/j.1469-7998.1975.tb01401.x
Hebert PDN, Penton EH, Burns JM, Janzen DH, Hallwachs W (2004) Ten species in one: DNA barcoding reveals cryptic species in the neotropical skipper butterfly Astraptes fulgerator. Proc Natl Acad Sci 101:14812-14817

Hinton HE (1956) The larvae of the species of Tinidae of economic importance. Bull Entomol Res 47:251-346

Kalle R, Ramesh T, Qureshi Q, Sankar K (2012) Diet of mongoose in Mudumalai Tiger Reserve, southern India. Sci Trans Environ Technovation 6:44-51

Karremans AP, Pupulin F, Grimaldi D, Beentjes KK, Butôt R, Fazzi GE, Kaspers K, Kruizinga J, Roessingh P, Smets EF, Gravendeel B (2015) Pollination of Specklinia by nectar-feeding Drosophila: the first reported case of a deceptive syndrome employing aggregation pheromones in Orchidaceae. Ann Bot 116:437-455. https://doi.org/10.1093/aob/mcv086

Kurahashi H, Benjapong N, Omar B (1997) Blow flies (Insecta: Diptera: Calliphoridae) of Malaysia and Singapore. Raffles Bull Zool 5:1-88

Litvaitis JA, Pearl MC (2000) Investigating food habits of terrestrial vertebrates. In: Boitani L, Fuller TK (eds) Research techniques in animal ecology. Columbia University Press, New York, pp $165-190$

Macías-Hernández N, Athey K, Tonzo V, Wangensteen OS, Arnedo M, Harwood JD (2018) Molecular gut content analysis of different spider body parts. PLoS ONE 13:e0196589

Mahmood T, Adil A (2017) Diet composition of small Indian mongoose (Herpestes javanicus) varies seasonally in its native range. Anim Biol 67:69-80. https://doi.org/10.1163/15707 563-00002516

Marquina D, Andersson AF, Ronquist F (2019) New mitochondrial primers for metabarcoding of insects, designed and evaluated using in silico methods. Mol Ecol Resour 19:90-104. https://doi. org/10.1111/1755-0998.12942

Monterroso P et al (2019) Feeding ecological knowledge: the underutilised power of faecal DNA approaches for carnivore diet analysis. Mamm Rev 49(2):97-112

Mumma MA, Adams JR, Zieminski C, Fuller TK, Mahoney SP, Waits LP (2016) A comparison of morphological and molecular diet analyses of predator scats. J Mammal 97:112-120. https://doi. org/10.1093/jmammal/gyv160

Ratnasingham S, Hebert PDN (2007) The barcode of life data system (www.barcodinglife.org). Mol Ecol Notes 7:355-364. https://doi. org/10.1111/j.1471-8286.2006.01678.x

Robinson MH, Pratt T (1975) The phenology of Hexacentrus mundus (F. Walker) at Wau, Papua New Guinea (Orthoptera, Tettigoniidae). Psyche J Entomol 82:3-4. https://doi.org/10.1134/s0374 064117080118

Seaman GA, Randall JE (1962) The mongoose as a predator in the Virgin Islands. J Mammal 43:544-546

Shehzad W, Mccarthy TM, Pompanon F, Purevjav L, Riaz T, Taberlet P (2012) Prey preference of snow leopard (Panthera uncia) in South Gobi, Mongolia. PLoS ONE 7:1-8. https://doi.org/10.5061/ dryad.bj376f61

Taberlet P, Bonin A, Coissac E, Zinger L (2018) Environmental DNA: for biodiversity research and monitoring. Oxford University Press, Oxford

Turbanova AA, Turbanov IS, Gorbunov OG (2019) To the knowledge of the biology and distribution of Monopis crocicapitella (Clemens, 1860) (Lepidoptera: Tineidae), with remarks on cavernicolous Lepidoptera. Russ Entomol J 28:72-81. https://doi. org/10.15298/rusentj.28.1.12

Veron G, Jennings AP (2017) Javan mongoose or small Indian mongoose-who is where? Mamm Biol 87:62-70

Veron G, Patou M-L, Pothet G, Simberloff D, Jennings AP (2007) Systematic status and biogeography of the Javan and small Indian mongooses (Herpestidae, Carnivora). Zool Scr 36:1-10 
Way M, Khoo KC (1992) Role of ants in pest management. Annu Rev Entomol 37:479-503. https://doi.org/10.1146/annur ev.ento.37.1.479

Zeale MRK, Butlin RK, Barker GLA, Lees DC, Jones G (2011) Taxon-specific PCR for DNA barcoding arthropod prey in bat faeces. Mol Ecol Resour 11:236-244. https://doi.org/10.111 1/j.1755-0998.2010.02920.x
Publisher's Note Springer Nature remains neutral with regard to jurisdictional claims in published maps and institutional affiliations. 